Vol. 12, No. 1, 2018, hal 1-8

\title{
Pengaruh latar belakang pendidikan dan bimbingan orang tua terhadap motivasi belajar siswa
}

\author{
Sri Rezeki Astuti, Salfiyah Isma Dayanti, Nujumul Laily \& Raudhah Aisyu Hasanah \\ Univertas Ibn Khaldun (UIKA) Bogor \\ srirezekyastuti22@gmail.com
}

\begin{abstract}
ABSTRAK
Penelitian ini dilatar belakangi hasil pengamatan dan pengalaman peneliti bahwa motivasi belajar siswa tergolong rendah, masih banyak siswa yang kurang aktif dalam pembelajaran. Adapun tujuan penelitian yang akan kami lakukan yaitu untuk: 1) Untuk menganalisis latar belakang pendidikan orang tua Mts Darul Himmah. 2) Untuk menganalisis seberapa penting bimbingan orang tua dalam motivasi belajar siswa Mts Darul Himmah. 3) Untuk menganalisis pengaruh latar belakang pendidikan dan bimbingan orang tua terhadap motivasi belajar siswa MTs Darul Himmah Depok.Penelitian ini menggunakan pendekatan kuantitatif dengan jumlah sampel 77 siswa.Teknik pengumpulan data menggunakan angket. Data yang telah diperoleh kemudian dianalisis dengan menggunakan uji regresi linear ganda dengan SPSS 16. Berdasarkan data SPSS 16, diperoleh nilai $F_{\text {hitung }}$ sebesar 10,212 dengan nilai probalitas (Sig) 0,000.karena nilai probalitas (Sig) $0,000<0,05$ maka model persamaaan regresi berdasarkan data penelitian adalah signifikan.Model persamaan regresi berganda untuk memperkirakan motivasi belajar siswa yang dipengaruhi oleh latar belakang pendidikan dan bimbingan orang tua adalah $5.632+0.120 \mathrm{X}_{1}+$ $0.342 \mathrm{X}_{2}$. Kesimpulan penelitian ini yaitu latar belakang pendidikan orang tua tidak memiliki pengaruh yang signifikan terhadap motivasi belajar siswa.Terdapat pengaruh yang signifikan antara bimbingan orang tua terhadap motivasi belajar siswa.
\end{abstract}

Kata Kunci : Bimbingan, Motivasi, Pendidikan.

\begin{abstract}
This research is motivated by the results of observations and experiences of researchers that student motivation is relatively low, there are still many students who are less active in learning. The purpose of the research we will do is to: 1) To analyze the educational background of MTs Darul Himmah's parents. 2) To analyze how important parental guidance is in students' motivation in MTs Darul Himmah. 3) To analyze the influence of educational background and parental guidance on student motivation in MTs Darul Himmah Depok. This study uses a quantitative approach with a sample of 77 students. Data collection techniques using questionnaire. The data obtained were then analyzed using the multiple linear regression test with SPSS 16. Based on the SPSS 16 data, a Fount value of 10.212 was obtained with a probability value (Sig) of 0.000. Because the probability value (Sig) of $0,000<0.05$, the regression equation model was based the research data is significant. The multiple regression equation models for estimating student motivation is influenced by educational background and parental guidance is 5,632 +0.120X $+0.342 X_{2}$. The conclusion of this study is that the educational background of parents does not have a significant effect on student motivasion. There is a significant influence between parental guidance on student motivasion.
\end{abstract}

Key word: guidance, motivation, educational. 


\section{Pendahuluan}

Pendidikan merupakan hal terbesar yang selalu diutamakan oleh para orang tua. Saat ini masyarakat semakin menyadari pentingnya pendidikan yang terbaik kepada anakanak mereka sejak dini.

Berkaitan dengan pendidikan fenomena-fenomena dan permasalahan yang terjadi saat ini pendidikan masyarakat Indonesia jauh tertinggal, sebanyak 49\% masyarakat hanya berpendidikan SD kebawah (Sindo News. Com, 2016). Nilai budaya baca secara nasional 25,1\% atau berada pada tingkat rendah (Sindo.Com, 2016).

Rata-rata lama pendidikan warga Indonesia yang berusia diatas 15 tahun hanya 8,42 tahun. Rata-rata lama pendidikan itu kurang lebih setara dengan jenjang SMP tapi tidak sampai lulus. Jika dilihat lebih detail lagi, sebanyak 20\% keluarga berpenghasilan terendah rata-rata pendidikannya hanya mencapai 6 tahun atau setara tamat SD.

Para orang tua yang memiliki tingkat pendidikan tinggi biasanya memiliki cita-cita yang tinggi pula pada anak-anaknya. Mereka menginginkan agar pendidikan anakanaknya lebih tinggi atau setidaknya sama dengan pendidikan orang tua mereka. Seberapapun keadaan tingkat pendidikan orang tua menginginkan anaknya lebih tinggi pendidikannya dibandingkan dirinya. Orang tua yang memiliki tingkat pendidikan yang lebih tinggi memang memiliki sumber daya yang cenderung lebih besar, baik pendapatan, waktu, tenaga, dan jaringan kontak yang memungkinkan mereka untuk terlibat lebih jauh dalam pendidikan anaknya (Andrayani,2017).

Untuk itu orang tua memegang peran penting dalam membimbing dan memberikan motivasi kepada anak dalam kehidupan keseharian anak. Orang tua merupakan lembaga pendidian utama dan pertama bagi anak-anak mereka, karena dari merekalah anak pertama kali menerima pendidikan. Dengan demikian pondasi pendidikan pertama kali ditanamkan dalam lingkungan keluarga. (Daradjat, 2016). Motivasi keluarga akan menjadi sangat penting tidak hanya melihat anaknya belajar dirumah tetapi harus mensuport kebutuhan-kebutuhan anak di dunia pendidikannya (Endin Mujahidin, 2019).

Keterkaitan orang tua dalam hal ini sangat penting, apalagi jika dilihat dalam pendidikan. Salah satu contohnya, apabila ada pekerjaan rumah (PR) yang tidak bisa dijawab, orang tua sebaiknya membantu dan membimbing anaknya. Sehingga peran orang tua tidak hanya sekedar memberikan uang jajan atau menyekolahkan anak tetapi juga ikut berperan dalam proses pendidikan anaknya. Dalam proses pendidikan semua terlibat, dan oleh karenanya baik guru, siswa, dan orang tua harus kreatif.

Selama ini sebagian orang tua berpikir bahwa pendidikan itu hanya merupakan tanggung jawab sekolah. Orang tua yang lebih utama membimbing anaknya dirumah agar termotivasi untuk belajar, tidak hanya bergantung kepada guru sekolah. Factor orang tua sangat berpengaruh pada keberhasilan anak. Tinggi rendahnya pendidikan sangat berpengaruhi prestasi anak.

Kondisi pendidikan saat ini, memunculkan semakin banyak tantangan-tantangan yang harus dihadapi. Hasil akhir yang didapatkan oleh siswa nyatanya belum bisa untuk 
membawa harum pendidikan yang ada di indonesia. Kemudian, kualitas terkait dengan proses belajar mengajar patut untuk di pertanyakan, apalagi ditambah dengan kondisi saat ini yang menunjukkan masih rendahnya motivasi belajar pada peserta didik. Motivasi sangat dibutuhkan dalam proses belajar hal ini dikarenakan siswa tidak mungkin melakukan proses belajar jika mereka tidak memiliki motivasi untuk belajar (Balqis, dkk 2014).

Bimbingan merupakan bantuan yang diberikan pada individu atau kelompok agar mereka itu dapat mandiri melalui berbagai bahan interaksi, nasehat, gagasan, alat dan asuh atas norma-norma yang berlaku (Chasanatin, 2010).

Bimbingan orang tua adalah petunjuk atau penjelasan cara mengerjakan sesuatu hal yang dilakukan oleh orang tua terhadap anak-anaknya. Diantara orang tua yang layak memberikan bimbingan dalam keluarga adalah Ayah dan Ibu.

Interaksi antara orang tua dan anak sangatlah penting bagi perkembangan psikologis anak didik. Orang tua dituntut untuk mendidik dan membimbing anak agar anak menjadi cerdas baik akhlaknya, dan menjadi manusia yang bermanfaat dikemudian hari. Pola asuh dapat dikuatkan self awereness (kesadaran diri) dan self control (control diri) anak bila tepat menerapkannya.

Motivasi belajar mempunyai fungsi sebagai energy penggerak terhadap tingkah laku, menentukan arah pembuatan, dan menentukan intensitas suatu perbuatan. Motivasi mendorong seseorang melakukan sesuatu untuk mencapai tujuan yang ingin dicapainya (Sardiman,2014).

Motivasi belajar adalah suatu pendorong yang berasal dari dalam diri seseorang guna melakukan kegiatan belajar untuk memperoleh pengetahuan serta keterampilan dan pengalaman (Nurmala, dkk 2014). Adapun motivasi belajar siswa dipengaruhi oleh dua aspek, yaitu aspek dalam diri (Internal) dan luar (eksternal) seperti orang tua,guru,dan teman sebaya.

Adapun upaya yang dilakukan orang tua untuk meningkatkan motivasi belajar anak dalam proses belajarnya yaitu (1). Memasukan anak kesekolah formal. (2). Menanamkan nilai luhur norma-norma, cita-cita, tingkah laku dan aspirasi dengan bimbingan orang tua dirumah. (3). Melakukan kerja sama antara lembaga pendidikan dengan orang tua.

\section{METODOLOGI PENELITIAN}

Jenis Penelitian ini merupakan penelitian lapangan, yaitu penelitian yang langsung dilaksanakan di lapangan atau kehidupan yang sebenarnya secara spesifik dan realis tentang apa yang terjadi (Mardalis, 1995: 28) Penelitian ini dilaksanakan di MTs Daarul Himmah Depok.

Pendekatan dalam penelitian ini adalah kuantitatif yaitu penelitian yang prosedurnya menekankan analisisnya pada data numerical (angka) yang diolah dengan metode statistic, kemudian untuk pembahasan yang digunakan adalah komparasi yaitu penelitian yang berusaha untuk menemukan persamaan dan perbedaan tentang benda, tentang orang, tentang prosedur 
kerja, tentang ide, kritik terhadap orang, kelompok, terhadap suatu ide atau suatu prosedur kerja (Sudijono, 1992: 260). Adapun yang menjadi variabel dalam penelitian ini adalah: Variabel X : Latar Belakang Pendidikan dan Bimbingan orang tua dan Variabel Y : Pengaruh Motovasi Terhadap hasil belajar.

Populasi adalah keseluruhan subjek penelitian (Arikunto, 1998: 115) adapun yang menjadi populasi dalam penelitian ini adalah siswa-siswi MTS Darul Himmah Depok kelas 8 \& 9 sebanyak 77 siswa.

Metode pengambilan sampel yang digunakan adalah stratified proportional random sampling. Sampel adalah sebagian atau wakil populasi yang diteliti (Arikunto, 1998: 117). Apabila subjek kurang dari 100 sebaiknya diambil semua sehingga penelitiannya merupakan penelitian populasi (Arikunto, 1998: 120).

\begin{tabular}{|l|l|l|}
\hline No & Kelas & Jumlah Sampel \\
\hline 1 & 8 MTS & 37 Siswa \\
\hline 2 & 9 MTS & 40 Siswa \\
\hline Jumlah & 77 Siswa \\
\hline
\end{tabular}

Instrument penelitian adalah alat atau fasilitas yang digunakan oleh peneliti dalam mengumpulkan data penelitian agar pekerjaannya menjadi lebih mudah untuk diolah.

Instrument penelitian menurut Sugiyono adalah "Suatu alat yang digunakan untuk mengukur fenomena alam maupun sosial yang diamati". Dari pengertian tersebut dapat difahami bahwa instrument merupakan suatu alat bantu yang digunakan oleh peneliti dalam menggunakan metode pengumpulan data secara sistematis dan lebih mudah. Instrument penelitian menempati posisi teramat penting dalam hal bagaimana dan apa yang harus dilakukan untuk memperoleh data dilapangan. Adapun instrument yang digunakan adalah pedoman observasi, pedoman angket, serta pedoman dokumentasi.

Dalam memperoleh data penelitian ini penulis menggunakan metode kuesioner. Metode ini dilakukan dengan cara mengajukan daftar pertanyaan kepada responden, untuk memperoleh data yang sebenarnya. Angket ini diberikan kepada siswa kelas 8 \& 9 MTs Darul Himmah. Angket adalah sejumlah pertanyaan tertulis yang digunakan untuk memperoleh informasi dari responden dalam arti laporan tentang pribadinya atau hal-hal yang ia ketahui (Arikunto 1998: 140). Selain itu, kuesioner juga cocok digunakan bila jumlah responden cukup besar dan tersebar diwilayah yang luas.

Kuesioner menggunakan skala Likert, yang terdiri dari:

Sangat tidak Setuju (STS), diberi bobot 1

Tidak Setuju (TS), diberi bobot 2

Setuju (S), diberi bobot 3

Sangat Setuju (ST), diberi bobot 4

Setelah itu keseluruhan skor yang fikumpulkan kemudian dijumlahkan dan diolah dengan menggunakan SPSS (statistical Product And Service Solution). Selanjutnya dilakukan 
perhitungan bobot nilai pada setiap jawaban responden akan dihitung untuk mendapatkan nilai persen $(\%)$ dan frekuensinya.

\section{HASIL PENELITIAN DAN PEMBAHASAN}

A. Hasil penelitian

Hasil Analisis Latar Belakang Pendidikan Dan Bimbingan Orang Tua Terhadap Motivasi Belajar Siswa.

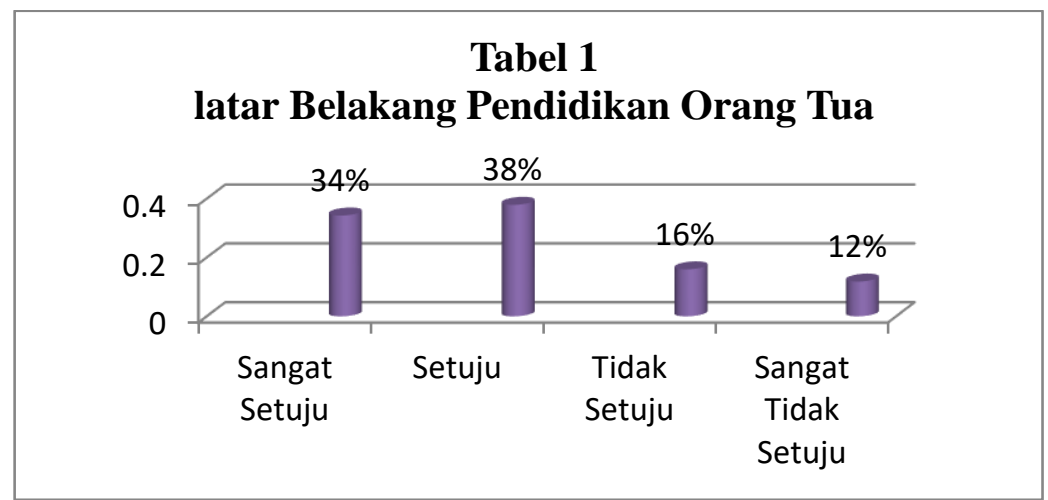

Table diatas menunjukan bahwa Frekuensi latar belakang pendidikan orang tua berada pada kategori tinggi sebesar 292 (38\%)

Hasil Analisis Deskriptif Bimbingan Orang Tua Terhadap Motivasi Belajar Siswa.

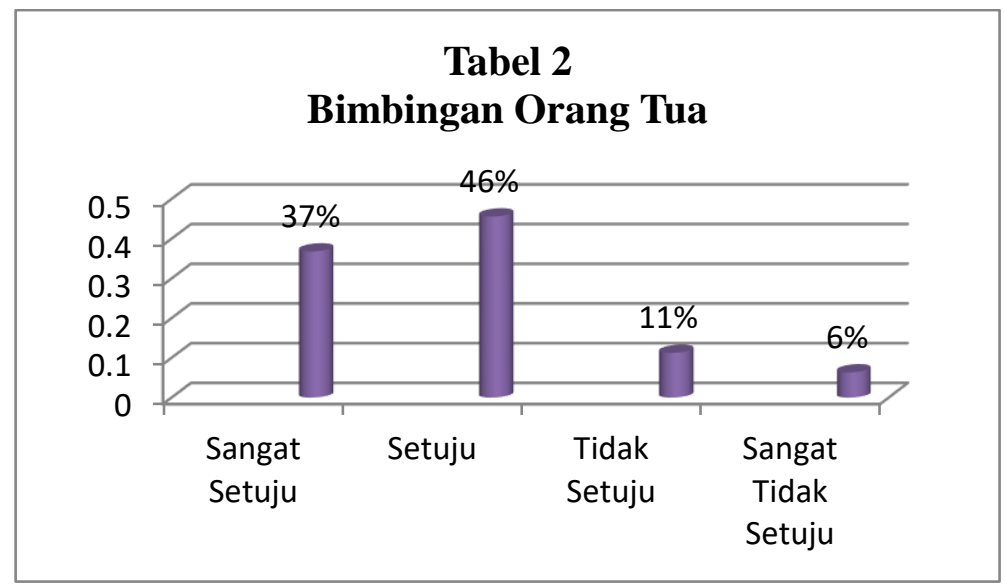

Tabel diatas menunjukan bahwa frekuensi bimbingan orang tua yang berada pada kategori tinggi sebesar 316 (46\%).

Hasil Analisis Deskritif Motivasi Belajar Siswa. 


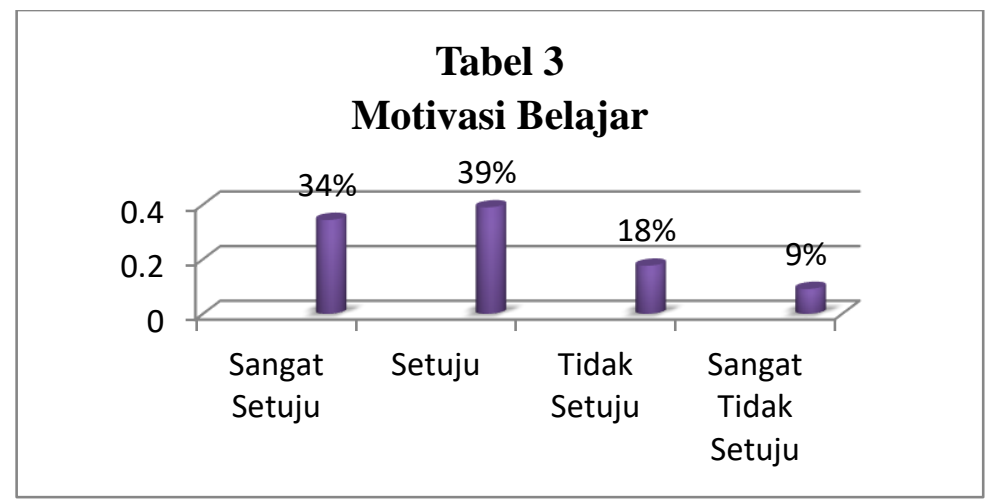

Table diatas menunjukan bahwa frekuensi motivasi belajar siswa yang berada pada kategori tinggi sebesar $330(39 \%)$.

\section{B. Pembahasan}

1. Latar Belakang Pendidikan orang tua $\left(X_{1}\right)$ Terhadap motivasi belajar siswa (Y) MTs Daarul Himmah Depok.

Nilai korelasi $(r)=0,302$. Nilai ini dapat diinterprestasikan bahwa latar belakang pendidikan orang tua terhadap motivasi belajar siswa adalah positif. Sedangkan untuk menyatakan besar kecilnya kontribusi (sumbangan variabel $\mathrm{X}_{1}$ dan $\mathrm{Y}$ atau koefisien determinasinya $=r^{2} \times 100 \%$ atau $0,302 \times 0,302 \times 100 \%=9,12 \%$. Hal ini berarti latar belakang pendidikan orang tua $\left(\mathrm{X}_{1}\right)$ memberikan kontribusi sebesar $9,12 \%$ terhadap motivasi belajar siswa (Y) dan sisanya 90,88\% ditentukan oleh faktor-faktor lain yang tidak diselidiki dalam penelitian ini.

Berdasarkan perhitungan menggunakan program SPSS 16 dengan ketentuan $a=0,05$,

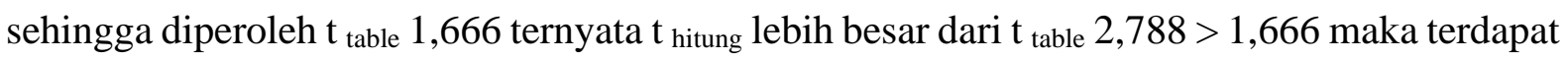
hubungan yang signifikan antara latar belakang pendidikan orang tua $\left(\mathrm{X}_{1}\right)$ terhadap motivasi belajar siswa (y) dengan demikian dapat disimpulkan bahwa jika latar belakang pendidikan orang tua, maka motivasi belajar siswa MTs Daarul Himmah Depok juga tinggi, sehingga hipotesis yang diperoleh dalam penelitian ini adalah penolak $\mathrm{H}_{\mathrm{o}}$ dan Menerima $\mathrm{H}_{1}$.

Nilai sig $=0,07<a=0,05$. Maka $H_{o}$ ditolak. Artinya hipotesis yang diajukan oleh peneliti diterima kebenarannya.

\section{Bimbingan orang tua $\left(X_{2}\right)$ terhadap motivasi belajar siswa (Y) MTs Daarul Himmah Depok.}

Nilai korelasi $(r)=0,401$. Nilai ini dapat di interpretasikan bahwa hubungan antara bimbingan orang tua terhadap motivasi belajar siswa adalah positif. Nilai koefisien determinasinya $=r^{2} \times 100 \%$ atau $0,401 \times 100 \%=16,10 \%$. Hal ini berarti bimbingan orang tua $\left(\mathrm{X}^{2}\right)$ memberikan kontribusi sebesar $16,10 \%$ terhadap motivasi belajar siswa $(\mathrm{Y})$. nilai sig $=$ $0,00>a=0,05$. Maka $H_{o}$ ditolak dan $H_{a}$ sehingga hipotesis yang diajukan oleh peneliti diterima kebenarannya.

\section{Latar Belakang Pendidikan Orang Tua $\left(X_{1}\right)$,Bimbingan Orang Tua $\left(X_{2}\right)$ Terhadap Motivasi Belajar Siswa (Y) pada MTs Daarul Himmah Depok.}


Berdasarkan data SPSS 16,table anova diperoleh nilai $F_{\text {hitung }}$ sebesar 10,212 dengan nilai probalitas (Sig) 0,000.karena nilai probalitas (Sig) 0,000 $<0,05$ maka model persamaaan regresi berdasarkan data penelitian adalah signifikan.Model persamaan regresi berganda untuk memperkirakan motivasi belajar siswa yang dipengaruhi oleh latar belakang pendidikan dan bimbingan orang tua adalah $5.632+0.120 \mathrm{X}_{1}+0.342 \mathrm{X}_{2}$.

Berdasarkan model persamaan regresi tersebut, dapat disimpulkan bahwa:

Nilai konstanta $\mathrm{a}=5.632$ ini dapat diartikan bahwa jika tidak ada latar belakang pendidikan orang tua $\left(\mathrm{X}_{1}\right)$, dan bimbingan orang tua $\left(\mathrm{X}_{2}\right)$, maka nilai konsisten dari motivasi belajar (Y) adalah 5.632.

Nilai koefisien regresi positif. Hal ini dapat diartikan bahwa variable $\mathrm{X}_{1}$ tidak berpengaruh terhadap variable Y. Dengan kata lain, setiap penambahan tingkat latar belakang pendidikan orang tua tidak akan meningkatkan motivasi belajar siswa.

Nilai Fhitung sebesar 10.212 dengan taraf signifikansi 0,000 memberikan arti bahwa variabel bimbingan orang tua berpengaruh terhadap motivasi belajar siswa (Y) pada MTs Daarul Himmah Depok. Koefisien determinasinya $=r^{2}$ X 100\% atau 0,465 X 0,465 X $100 \%=0,216$ artinya $21,6 \%$ motivasi belajar siswa dapat dijelaskan oleh variabel bimbingan orang tua terhadap motivasi belajar. Sisanya 78,4\% dijelaskan oleh faktor selain bimbingan orang tua terhadap yang dapat mempengaruhi motivasi belajar siswa.

\section{KESIMPULAN}

Berdasarkan hasil analisis data penelitian maka peneliti berkesimpulan bahwa pertama, latar belakang pendidikan orang tua pada MTs Daarul Himmah Depok berada dalam kategori tinggi. Kedua, bimbingan orang tua pada MTs Daarul Himmah Depok berada dalam kategori tinggi. Ketiga, motivasi belajar siswa pada MTs Daarul Himmah Depok berada dalam kategori tinggi. Keempat, latar belakang pendidikan orang tua tidak memiliki pengaruh positif yang signifikan terhadap motivasi belajar siswa. Kelima, bimbingan orang tua memiliki memiliki pengaruh positif yang signifikan terhadap motivasi belajar siswa.

\section{DAFTAR PUSTAKA}

Waidi, Didin Saefudin,dan Endin Mujahidin,2019. Pengaruh motivasi keluarga terhadap prestasi belajar siswa: Studi kasus di MTs Al-Azhar Tuwel. Jurnal pendidikan Islam Volume 8/No:02:hal.212

Suharsimi Arikunto. Prosedur Penelitian. Jakarta : Rineka Cipta.2014

Fajriyah Nurhidayah. 2012. Hubungan antara dukungan orang tua dengan motivasi belajar siswa di SD Negeri Bumi satu Laweyan Surakarta.

Didik Kurniawan. 2014. Pengaruh perhatian orang tua, moyivasi belajar, dan lingkungan social terhadap prestasi belajar matematika siswa SMP. Jurnal Riset Pendidikan Matematika. Volume 1 (2): Hal.186

Septian Kurnia \& Sugeng Muslimin. 2017. Pengaruh latar belakang pendidikan formal orang tua terhadap motivasi belajar peserta didik kelas VIII dalam mata pelajaran IPS di SMPN 1 Lemahabang Kabupaten Cirebon. Jurnal Edunomic. Volume 5 (01): 


\section{Hal.54-55}

Arlinda Restuadyani Maghfirro. 2017. Pengaruh latar belakang orang tua terhadap hasil belajar siswa di SMA Negeri 1 Gedeg Kabupaten Mojekerto. Edisi Yudisium. Volume 5 (1): Hal.6

Wening Patmi Rahayu. 2011. Analisis intensitas pendidikan oleh orang tua dalam kegiatan belajar anak, status social ekonomi orang tua terhadap motivasi belajar dan prestasi belajar siswa. Jurnal Pendidikan dan Pembelajaran. Volume 18 (1): Hal.79

Tety Nur Cholifah, I Nyoman Sudana Degeng, Sugeng Utaya. 2016. Pengaruh latar belakang tingkat pendidikan orang tua dan gaya belajar terhadap hasil belajar siswa pada kelas IV SDN Kecamatan Sanawetan Kota Blitar. Jurnal Pendidikan. Volume 1 (3): Hal.490

Putra Dinata, Mega Iswari, Mudjiran. 2016. Kontribusi konsep diri dan dukungan orang tua terhadap motivasi belajar siswa dan implikasinya dalam pelayanan bimbingan dan konseling. Konseling. Volume 5 (1): Hal.11

Anindhiya Setyaningrum. 2015. Pengaruh dukungan social orang tua terhadap motivasi berprestasi siswa kelas V Sekolah Dasar. Jurnal Pendidikan Guru Sekolah Dasar.

Nike Pratiwi Suciningrum \& Endang Sri Rahayu. 2015. Pengaruh social ekonomi orang tua dan motivasi belajar terhadap minat melanjutkan studi ke perguruan tinggi pada kelas XI di SMA Pusaka 1 Jakarta. Jurnal Pendidikan Ekonomi dan Bisnis. Volume 3 (1): Hal.18-19 